\title{
Serum uric acid in England and Scotland
}

\author{
R. A. STURGE, ${ }^{1}$ J. T. SCOTT, ${ }^{1}$ A. C. KENNEDY, ${ }^{2}$ D. P. HART, ${ }^{3}$ AND W. WATSO \\ BUCHANAN ${ }^{2}$
}

From Charing Cross Hospital and Kennedy Institute of Rheumatology, London; ${ }^{1}$ Centre for Rheumatic Diseases, Glasgow; ${ }^{2}$ and University of Birmingham ${ }^{3}$

SUMMARY Serum uric acid (SUA) was measured in 512 men and 254 women from two English regions and in 337 men from one Scottish region. Mean SUA levels were the same in the ment $(5.5 \mathrm{mg} / 100 \mathrm{ml})$ and similar in the women $(3.9$ and $4.1 \mathrm{mg} / 100 \mathrm{ml})$. The apparent rarity of gowt in Scotsmen cannot be explained by regional differences in SUA levels or in the prevalence of hyperuricaemia (defined as SUA of $7.0 \mathrm{mg} / 100 \mathrm{ml}$ or over) which was present in $6.6 \%$ of the English men and $8 \%$ of the Scots. SUA was positively correlated with weight and serum urea, and with age in women, but no variation was found with social class. Body weight was the most important predictor of SUA in both men and women and superior to measurements involving correction for height, such as ponderal index and calculated lean body mass.

'In Scotland gout is much less frequently met with than in England .... and when it does occur it is generally in the upper classes of society and in larger cities, where wines and ales have been largely substituted for whisky. . . . Sir Robert Christison bears similar testimony, for he informed me that he had met with only two cases of gout in the (Edinburgh) infirmary, although physician to it for 30 years, and both subjects were fat and overfed English butlers'. A. B. Garrod in Gout and Rheumatic Gout, 3rd ed. 1876

The prevalences of gout and of hyperuricaemia are known to vary considerably between population groups in different parts of the world (Healey and Hall, 1970). One hundred years ago A. B. Garrod wrote that gout was far less common in Scotland than in England, a view which continues to be held, though actual data on this are lacking. In the absence of recent hypouricaemic therapy, hyperuricaemia is a prerequisite for the diagnosis of gout; it was therefore decided to compare serum uric acid (SUA) levels between adults in England and Scotland. At the same time the opportunity was taken to investigate other factors which are possibly related to SUA levels, such as physique, blood urea, and social class.

Accepted for publication May 2, 1977

Correspondence to Dr. J. T. Scott, Kennedy Institute of Rheumatology, Bute Gardens, Hammersmith, London W6 7DW

\section{Methods}

A total of 1103 subjects took part in the surveg, comprising 341 male and 52 female employees of the Atomic Energy Research Establishment, Winfrit Dorset, England; 171 male and 202 female blo donors attending the Regional Blood Transfusion Centre, Birmingham, England; and 337 ma裙 employees of three light industry establishments the Glasgow, Scotland area. (The number of fema表 subjects from Glasgow (6) was too small for statistical analysis.) Subjects were interviewed either blood donor sessions (Winfrith and Birmingham) or routine medical examinations (Glasgow) and asked to donate $10 \mathrm{ml}$ blood. A record was made of each subject's sex, height, weight, apd occupation, the last being coded into social class according to the Registrar General's Classification of Occupations (1970).

The serum was immediately separated from eaen blood sample and stored at $-20^{\circ} \mathrm{C}$. When collections had been completed the sera were transported frozen to Charing Cross Hospital, Londo for analysis. Mean storage time was $6 \cdot 1$ montks. Serum urea and uric acid were measured colosmetrically on a Technicon autoanalyser (Technicin AA1-N30) in randomized batches of 30 sera for each run. The analysis sessions took place over three weekends and were carried out by the same seniof technician and two assistants. Quality and droft control checks were carried out at frequent intervals throughout each session. As a final check three 
samples from each run were carried over to the next run to exclude inter-batch variation. Daily means were calculated for each of the three regional gioups and showed no significant variation.

\section{Results}

\section{COMPARABILITY OF REGIONAL GROUPS}

For the purpose of analysis the subjects were divided by sex and region of domicile. Mean ages, weights, and serum ureas for each group are given in Table 1.

The ages were similar apart from those of the Winfrith men which were significantly higher than any of the other four groups $(P<0 \cdot 01)$. The Winfrith and Birmingham men were heavier than the Glasgow men $(P<0.001)$ and the Birmingham women were heavier than the Winfrith women $(P<0.05)$. The Birmingham men were taller than the Winfrith and Glasgow men $(\mathrm{P}<0.01)$ and the Birmingham women were taller than the Winfrith women $(P<0 \cdot 01)$. The Birmingham men had a lower mean serum urea than either of the other two males groups $(P<0.001)$. Combining the regions the men were of similar age (mean 37.2 years) to the women (mean 36.4 years) but heavier (mean $74.9 \mathrm{~kg}$ and $62.6 \mathrm{~kg}$ respectively; $\mathrm{P}<0.001$ ), taller (mean $175.3 \mathrm{~cm}$ and $162.9 \mathrm{~cm}$ respectively; $\mathrm{P}<0.001$ ), and with a higher blood urea (mean 30.8 and $26.4 \mathrm{mg} / 100 \mathrm{ml} \mathrm{(5.1}$ and 4.4 $\mathrm{mmol} / \mathrm{l})$ respectively; $\mathbf{P}<0.001$ ).

\section{FREQUENCY DISTRIBUTION OF SUA*}

The SUA values were grouped into $0.5 \mathrm{mg} / 100 \mathrm{ml}$ classes and plotted as a frequency distribution curve for each group (Fig. 1). The curves approximate a

* When the study was undertaken, uric acid levels were expressed in gravimetric $(\mathrm{mg} / 100 \mathrm{ml})$ rather than in SI (mmol/l) units, and frequency distribution curves were drawn in classes of gravimetric units. These are therefore retained in this paper, giving the additional advantage of easy comparison with previous epidemiological studies. To convert $\mathrm{mg} / 100 \mathrm{ml}$ to $\mathrm{mmol} / \mathrm{l}$, the figure should be multiplied by 0.0595 . normal distribution, being slightly skewed towards the higher values, particularly in the women. No individual values were less than $1.3 \mathrm{mg} / 100 \mathrm{ml}$ or greater than $8.9 \mathrm{mg} / 100 \mathrm{ml}$.

Uric acid levels for men were identical in the three regional groups, with a modal class of 5.5-5.9 $\mathrm{mg} / 100 \mathrm{ml}$ and a mean $( \pm \mathrm{SD})$ of $5 \cdot 5 \pm 1 \cdot 0 \mathrm{mg} / 100$ $\mathrm{ml}$. The modal class for the Winfrith women was $4 \cdot 0-4 \cdot 4 \mathrm{mg} / 100 \mathrm{ml}$ and for the Birmingham women $3 \cdot 5-3.9 \mathrm{mg} / 100 \mathrm{ml}$, the mean ( $\pm \mathrm{SD}$ ) being $4 \cdot 1 \pm 0 \cdot 8$ and $3 \cdot 9 \pm 0.8 \mathrm{mg} / 100 \mathrm{ml}$ respectively. Combining the two female groups the modal class was 3.5-3.9 $\mathrm{mg} / 100 \mathrm{ml}$ and the mean $3.9 \mathrm{mg} / 100 \mathrm{ml}$.

\section{AGE AND SUA}

The mean SUA values for each 5-year age class, separated by sex, are shown in Fig. 2. The regional groups have been combined as the individual group plots closely overlapped. For adult men there is no significant correlation between SUA and age. The slight terminal rise should be ignored as it represents only 4 subjects. In women, however, the levels fall slightly at age 30-34 and thereafter gradually rise, more sharply after age $45-49$, to reach a new higher level around age 55-59. Overall there is a significantly positive correlation between the individual SUA values in women with age and there is a highly significant difference $(t=4 \cdot 176, P<0.001)$ between the mean SUA in those under 50 (mean $3.8 \mathrm{mg} / 100$ $\mathrm{ml}$ ) and those 50 and over (mean $4.3 \mathrm{mg} / 100 \mathrm{ml}$ ). Analysis of variance confirmed that the differences between the age-specific mean SUA levels were unlikely to be due simply to sampling variations $(F=2 \cdot 756$; degrees of freedom $=9: 244 ; P<0 \cdot 01)$.

Although there was considerable overlap between the individual male and female SUA values at most age groups, the mean values were all significantly different at the $1 \%$ level or less, using the $t$ test.

WEIGHT AND SUA

The mean SUA levels for each $10-\mathrm{kg}$ weight class are shown in Fig. 3. The regional groups are combined as there were no significant differences in SUA

Table 1 Number of subjects from each region with mean age, weight, height, and blood urea

\begin{tabular}{|c|c|c|c|c|c|}
\hline & \multicolumn{3}{|l|}{ Men } & \multicolumn{2}{|l|}{ Women } \\
\hline & Winfrith & Birmingham & Glasgow & Winfrith & Birmingham \\
\hline $\begin{array}{l}\text { No. } \text { rf subjects } \\
\text { Mean age (years) } \\
\quad \pm \text { SD }\end{array}$ & $\begin{array}{l}341 \\
41 \pm 12\end{array}$ & $\begin{array}{l}171 \\
35 \pm 12\end{array}$ & $\begin{array}{l}337 \\
35 \pm 12\end{array}$ & $\begin{array}{l}52 \\
35 \pm 13\end{array}$ & $\begin{array}{l}202 \\
37 \pm 13\end{array}$ \\
\hline $\begin{array}{l}\text { Mean weight }(\mathrm{kg}) \\
\quad \pm \mathrm{SD}\end{array}$ & $75 \cdot 9 \pm 9 \cdot 5$ & $77 \cdot 5 \pm 10 \cdot 9$ & $72 \cdot 7 \pm 10 \cdot 3$ & $59 \cdot 9 \pm 6 \cdot 5$ & $63 \cdot 2 \pm 9 \cdot 6$ \\
\hline $\begin{array}{l}\text { Mean height }(\mathrm{cm}) \\
\pm S D\end{array}$ & $175 \cdot 3 \pm 6 \cdot 5$ & $177 \cdot 3 \pm 6 \cdot 7$ & $174 \cdot 4 \pm 6 \cdot 5$ & $160 \cdot 8 \pm 6 \cdot 5$ & $163 \cdot 4 \pm 6 \cdot 5$ \\
\hline $\begin{array}{l}\text { Mean serum urea } \\
(\mathrm{mg} / 100 \mathrm{ml}) \pm \mathrm{SD}\end{array}$ & $31 \cdot 3 \pm 6 \cdot 7$ & $28 \cdot 7 \pm 6 \cdot 1$ & $31 \cdot 4 \pm 6 \cdot 9$ & $25 \cdot 9 \pm 5 \cdot 8$ & $26 \cdot 5 \pm 6 \cdot 2$ \\
\hline
\end{tabular}

Conversion: Traditional units to SI-Urea: $1 \mathrm{mg} / 100 \mathrm{ml} \approx 0.166 \mathrm{mmol} / 1$. 
levels for each weight class. There is a trend for SUA to rise with weight and for individual values the correlation is significant at the $1 \%$ level. Correlations were also drawn with Ponderal Index (PI), that is $\mathrm{Ht} /(3 \sqrt{\mathrm{Wt}})$, and Lean Body Mass (LBM), calculated according to the formula of Hume and Weyers
(1971), and the results are shown in Table 2.

There was a significantly negative correlation with PI and a positive correlation with LBM but the correlation was no closer than that with weigtit. There was no correlation with height taken as variable in its own right, in either sex.

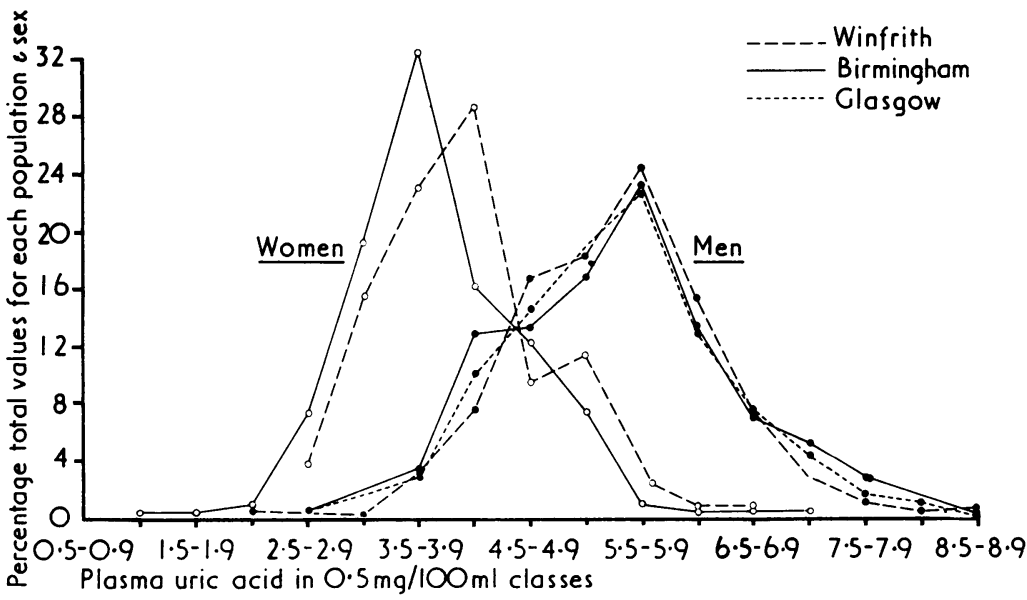

Fig. 1 Frequency distributi of serum uric acid levels for 0 men and women.
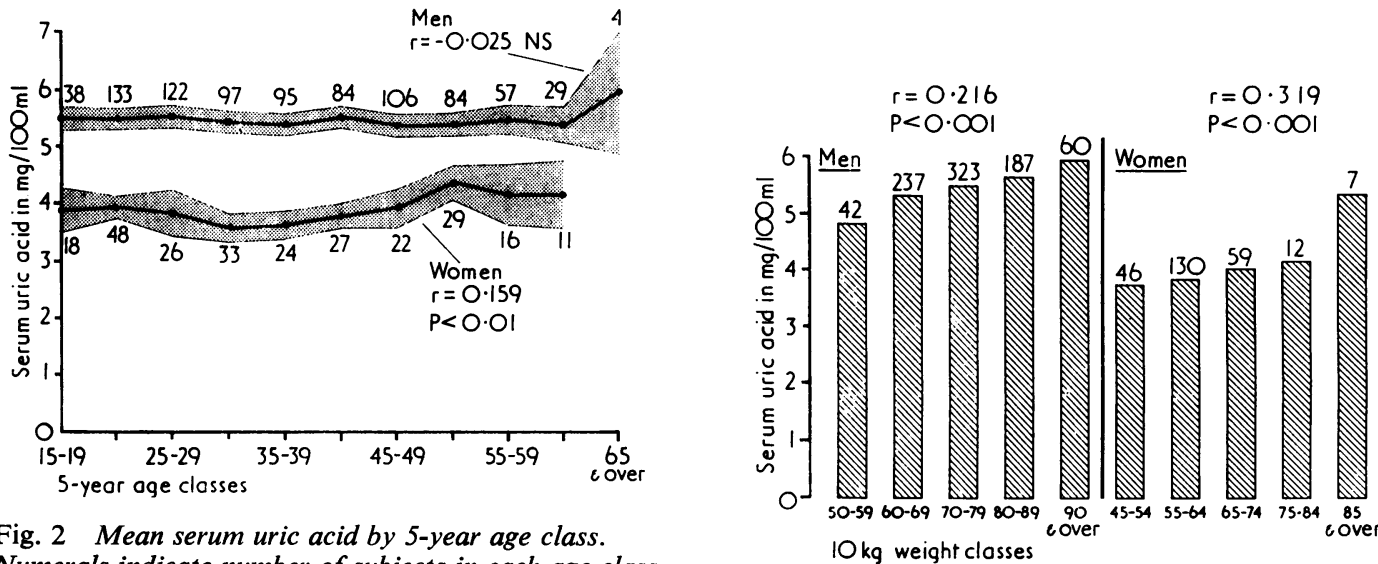

Fig. 2 Mean serum uric acid by 5-year age class.
Numerals indicate number of subjects in each age class and stippled area represents 2 standard errors on either side of mean.

Fig. 3 Mean serum uric acid by 10-kg weight class. Numerals indicate number of subjects in each weight clas

Table 2 Correlation coefficients for serum uric acid (SUA) with height, weight, ponderal index (PI), and lean body mas3

\begin{tabular}{|c|c|c|c|c|}
\hline & Height & Weight & $P I$ & $L B M$ \\
\hline Men & $r=0.55, P>0.1$ & $\mathrm{r}=0.216, \mathrm{P}<0.001$ & $r=-0.183, P<0.001$ & $r=0.190, P<0.001$ \\
\hline Women & $\mathrm{r}=-0.027, \mathrm{P}>0.1$ & $r=0.319, P<0.001$ & $r=-0.299, P<0.001$ & $r=0.146, P<0.01$ \\
\hline
\end{tabular}


SERUM UREA AND SUA

The mean SUA values for each $10 \mathrm{mg} / 100 \mathrm{ml}$ class in blood urea are shown in Fig. 4 for the combined men and combined women. There were again no significant differences between the regional groups in SUA levels at each urea class. There is a trend for SUA to rise with increasing serum urea; this takes place even within the generally accepted range for normal urea values. For individual values the correlation is significant at the $1 \%$ level in men and $5 \%$ level in women.

\section{HYPERURICAEMIA}

Individual SUA values of $7 \mathrm{mg} / 100 \mathrm{ml}$ or over were found in 19 Winfrith men $(5.6 \%), 15$ Birmingham men $(8.8 \%)$, and 27 Glasgow men $(8 \%)$, resulting in an overall prevalence of hyperuricaemia, defined in this way, of $7 \cdot 2 \%$. The regional differences were not significant using the $\chi_{2}$ test with Yates's correction. Only one woman $(0.4 \%)$ from Birmingham was hyperuricaemic.

Comparisons between the 788 normouricaemic and 61 hyperuricaemic men are shown in Table 3. The two groups were of similar age and PI but the hyperuricaemic men were significantly heavier with a greater LBM and higher blood urea levels than the normouricaemic individuals.

\section{MULTIPLE REGRESSION}

A stepwise regression analysis was carried out to determine the relative contributions of each of the independent variables, shown previously to be significantly correlated, as predictors of SUA. The results are given in Table 4.

Sex was by far the most important predictor of SUA, accounting for $33 \%$ of the total variation (percentage variation accounted for $=\mathbf{R}^{2} \times 100$ ), the other variables adding only another $6 \%$, although with the exception of PI their contribution to the SUA of the combined sexes were all statistically significant. Taking the sexes separately the variables considered accounted for $14 \%$ of the variation of SUA in the women but only for $8 \%$ in the men, with weight contributing $10 \%$ in the women and $5 \%$ in the men. PI and LBM were also more strongly correlated with SUA in the women than the men (Table 2) but only LBM in the women and PI in the men retained a significant contribution when entered

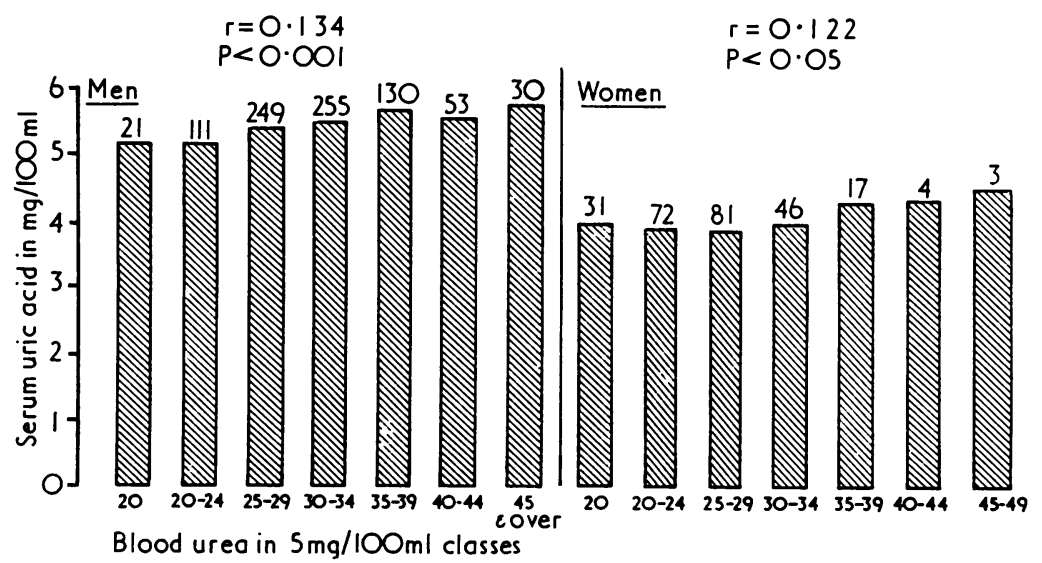

Fig. 4 Mean serum uric acid by $5 \mathrm{mg} / 100 \mathrm{ml}$ serum urea class. Numerals indicate number of subjects in each urea class. Conversion: Traditional units to SIUrea: $1 \mathrm{mg} / 100 \mathrm{ml} \approx 0 \cdot 166$ $\mathrm{mmol} / \mathrm{l}$.

Table 3 Comparisons between normouricaemic and hyperuricaemic men

\begin{tabular}{|c|c|c|c|c|}
\hline & Normouricaemic & Hyperuricaemic & $t$ & $P$ \\
\hline $\begin{array}{c}\text { Mean SUA } \pm \text { SD } \\
(\mathrm{mg} / 100 \mathrm{ml})\end{array}$ & $5 \cdot 3 \pm 0 \cdot 8$ & $7 \cdot 5 \pm 0 \cdot 5$ & 0.32 & $<0.001$ \\
\hline $\begin{array}{l}\text { Mean age } \pm \text { SD } \\
\text { (years) }\end{array}$ & $37 \cdot 3 \pm 12 \cdot 6$ & $36 \cdot 8 \pm 12 \cdot 6$ & $20 \cdot 16$ & NS \\
\hline $\begin{array}{l}\text { Mean urea } \pm \text { SD } \\
(\mathrm{mg} / 100 \mathrm{ml})\end{array}$ & $30 \cdot 7 \pm 6 \cdot 6$ & $33 \cdot 0 \pm 7 \cdot 2$ & 2.57 & $=0.01$ \\
\hline $\begin{array}{l}\text { Mean height } \pm \text { SD } \\
\text { (cm) }\end{array}$ & $175 \cdot 3 \pm 6 \cdot 6$ & $176 \cdot 4 \pm 7 \cdot 0$ & $1 \cdot 31$ & NS \\
\hline $\begin{array}{l}\text { Mean weight } \pm \text { SD } \\
(\mathbf{k g})\end{array}$ & $74 \cdot 6 \pm 10 \cdot 1$ & $78 \cdot 5 \pm 12 \cdot 6$ & $2 \cdot 86$ & $<0.01$ \\
\hline $\begin{array}{l}\text { Mean PI } \pm \text { SD } \\
\text { Mean LBM } \pm \text { SD }\end{array}$ & $\begin{array}{l}12 \cdot 6 \pm 0 \cdot 5 \\
57 \cdot 9 \pm 5 \cdot 1\end{array}$ & $\begin{array}{l}12 \cdot 5 \pm 0 \cdot 6 \\
59 \cdot 8 \pm 6 \cdot 3\end{array}$ & $\begin{array}{l}1 \cdot 64 \\
2 \cdot 71\end{array}$ & $\begin{array}{l}\text { NS } \\
<0.01\end{array}$ \\
\hline
\end{tabular}


Table 4 Stepwise regression of SUA with physique, blood urea, and age

\begin{tabular}{|c|c|c|c|c|c|c|c|c|c|}
\hline \multirow[b]{2}{*}{ Step } & \multicolumn{3}{|l|}{ Men } & \multicolumn{3}{|l|}{ Women } & \multicolumn{3}{|c|}{ Both sexes } \\
\hline & $\begin{array}{l}\text { Variable } \\
\text { added }\end{array}$ & $\boldsymbol{R}$ & $R^{2}$ & $\begin{array}{l}\text { Variable } \\
\text { added }\end{array}$ & $\boldsymbol{R}$ & $R^{2}$ & $\begin{array}{l}\text { Variable } \\
\text { added }\end{array}$ & $R$ & $R^{2}$ \\
\hline $\begin{array}{l}1 \\
2 \\
3 \\
4 \\
5 \\
6\end{array}$ & $\begin{array}{l}\text { Weight* } \\
\text { Urea* } \\
\text { Age* } \\
\text { PI } \dagger \\
\text { LBM } \\
\end{array}$ & $\begin{array}{l}0.216 \\
0.254 \\
0.272 \\
0.283 \\
0.285 \\
-\end{array}$ & $\begin{array}{l}0.047 \\
0.064 \\
0.074 \\
0.080 \\
0.081 \\
-\end{array}$ & $\begin{array}{l}\text { Weight* } \\
\text { LBM } \dagger \\
\text { Urea } \\
\text { PI } \\
\text { Age } \\
\end{array}$ & $\begin{array}{l}0.319 \\
0.349 \\
0.359 \\
0.366 \\
0.371 \\
-\quad\end{array}$ & $\begin{array}{l}0 \cdot 102 \\
0 \cdot 122 \\
0 \cdot 129 \\
0 \cdot 134 \\
0 \cdot 137 \\
-\end{array}$ & $\begin{array}{l}\text { Sex* } \\
\text { Weight* } \\
\text { Urea* } \\
\text { LBM* } \\
\text { Age* } \\
\text { PI }\end{array}$ & $\begin{array}{l}0.571 \\
0.603 \\
0.611 \\
0.615 \\
0.618 \\
0.618\end{array}$ & $\begin{array}{l}0.326 \\
0.363 \\
0.374 \\
0.378 \\
0.382 \\
0.382\end{array}$ \\
\hline
\end{tabular}

$* P<0.01 .+P<0.05$.

into the stepwise procedure; in neither case did this amount to more than $1 \%$ of the total variation of SUA. Interestingly, age, because of its association with previously entered variables, became insignificant as a predictor of SUA in women but attained a significant contribution in men. Similarly serum urea lost its significance in women but retained it in men.

\section{SOCIAL CLASS AND SUA}

The mean SUA values for each social class group are shown in Table 5. As there was under-representation of social class $\mathrm{V}$ this was combined with social class IV. Many of the Birmingham women gave their occupation as 'housewife' and were excluded from the analysis as this does not adequately represent their social class. Only in the Birmingham men was a consistent trend shown of SUA to rise with decreasing social class. As social class cannot be considered to be continuously distributed, the Birmingham figures were tested for significance by analysis of variance. No significant variation of SUA between the class groups was found $(F=1 \cdot 125$; degrees of freedom $3: 167$ ).

\section{Discussion}

By separating the blood immediately, storing the sera in the frozen state, and analysing them in randomized batches over a limited number of sessions in one laboratory, the technical and interlaboratory errors which can reduce the validity of population comparisons (Bywaters and Holloway,
1964) were minimized. The autoanalyser techniquife for measuring SUA is a colorimetric method apd has been reported by most investigators to gite readings 0.2 to $0.5 \mathrm{mg} / 100 \mathrm{ml}$ higher than the moge specific enzyme spectrophotometric method (Popert and Hewitt, 1962; O'Sullivan et al., 1965; Evañs et al., 1969; Dodge and Mikkelsen, 1970). However, in our laboratory, comparison of the two methods gives a mean level of $0.3 \mathrm{mg} / 100 \mathrm{ml}$ lower for tbe colorimetric method, as has been reported by other workers (Liddle et al., 1959), and an overall corre $\vec{a}-$ tion coefficient of $0 \cdot 97$. Storage should only improxle the reliability of the method as it allows nonspecific chromogens to decay (Buchanan et al., 1965).

Comparison of our findings with those of earleir surveys is difficult because of the above provisos aild also because earlier nonautomated colorimet? procedures tend to give lower readings, of the order of $0.4 \mathrm{mg} / 100 \mathrm{ml}$, than the automated method (Fion et al., 1966). Nevertheless, it is interesting to compare the present survey with the findings of other survess in Caucasian adults of a similar age range to our subjects. Table 6 gives the mean levels and ti percentage of those with an SUA of $7 \mathrm{mg} / 100 \mathrm{ml} \%$ over in surveys including over 100 subjects. Mean levels in the present study are higher than those oin the only previous large scale United Kingdom survey (Popert and Hewitt, 1962), a finding unlikely to be accounted for entirely by methodological differences. They are also higher in men than those in a Finnis survey (Isomäki and Takkunen, 1969). They arie similar to those of two surveys in the USA (Mikkô)-

Table 5 Social class and serum uric acid

\begin{tabular}{|c|c|c|c|c|}
\hline & \multicolumn{4}{|c|}{ Mean $S U A \pm S D$ for social class (numbers in parentheses) } \\
\hline & $I$ & $I I$ & $I I I$ & $I V \& V$ \\
\hline $\begin{array}{l}\text { Winfrith men } \\
\text { Birmingham men } \\
\text { Glasgow men }\end{array}$ & $\begin{array}{l}5 \cdot 5 \pm 1 \cdot 0(106) \\
5 \cdot 2 \pm 1 \cdot 0(20) \\
5 \cdot 4 \pm 0 \cdot 5(10)\end{array}$ & $\begin{array}{l}5 \cdot 5 \pm 0.9(45) \\
5 \cdot 3 \pm 0.9(25) \\
5 \cdot 5 \pm 1 \cdot 0(48)\end{array}$ & $\begin{array}{l}5 \cdot 5 \pm 0 \cdot 9(133) \\
5 \cdot 6 \pm 1 \cdot 0(111) \\
5 \cdot 5 \pm 1 \cdot 0(109)\end{array}$ & $\begin{array}{l}5 \cdot 3 \pm 0 \cdot 9(58) \\
5 \cdot 7 \pm 1 \cdot 0(15) \\
5 \cdot 5 \pm 1 \cdot 0(170)\end{array}$ \\
\hline $\begin{array}{l}\text { Winfrith women } \\
\text { Birmingham women }\end{array}$ & $\begin{array}{l}4 \cdot 1 \pm 0 \cdot 7(6) \\
3 \cdot 9 \pm 1 \cdot 0(16)\end{array}$ & $\begin{array}{l}4 \cdot 3 \pm 0.6(2) \\
3 \cdot 8 \pm 1 \cdot 0(24)\end{array}$ & $\begin{array}{l}3.9 \pm 0.7(34) \\
4.0 \pm 0.7(101)\end{array}$ & $\begin{array}{l}4 \cdot 7 \pm 0.8(10) \\
3 \cdot 7 \pm 0.6(17)\end{array}$ \\
\hline
\end{tabular}


Table 6 Mean SUA levels and percentage of hyperuricaemics in population surveys of over 100 subjects

\begin{tabular}{|c|c|c|c|c|c|c|}
\hline Author \& year & Location & $\begin{array}{l}\text { No. of } \\
\text { subjects }\end{array}$ & $\begin{array}{l}\text { Age range } \\
\text { (years) }\end{array}$ & $\begin{array}{l}\text { Mean } S U A \\
(\mathrm{mg} / 100 \mathrm{ml})\end{array}$ & $\begin{array}{l}\text { Percentage of subjects } \\
\text { with SUA } \\
7.0 \mathrm{mg} / 100 \mathrm{ml} \text { or over }\end{array}$ & Method \\
\hline $\begin{array}{l}\text { Men } \\
\text { Popert \& Hewitt (1962) } \\
\text { Acheson (1969) } \\
\text { Mikkelsen et al. (1965) } \\
\text { Hall et al. (1967) } \\
\text { Acheson \& O'Brien (1966) } \\
\text { Evans et al. (1969) } \\
\text { Jeremy \& Towson (1971) } \\
\text { Garrick et al. (1972) } \\
\text { Zalokar et al. (1972) } \\
\text { Isomäki \& Takkunen (1969) } \\
\text { Finn et al. (1966) } \\
\text { Present study }\end{array}$ & $\begin{array}{l}\text { Wensleydale, UK } \\
\text { Watford, UK } \\
\text { Tecumseh, USA } \\
\text { Framingham, USA } \\
\text { New Haven, USA } \\
\text { Carterton, NZ } \\
\text { Sydney, Australia } \\
\text { Sydney, Australia } \\
\text { Paris, France } \\
\text { Saloinen, Finland } \\
\text { Liverpool, UK } \\
\text { UK }\end{array}$ & $\begin{array}{r}411 \\
158 \\
2142 \\
2062 \\
534 \\
202 \\
500 \\
106 \\
23923 \\
737 \\
267 \\
849\end{array}$ & $\begin{array}{l}15-74 \\
\text { Adult } \\
15-74 \\
30-64 \\
>21 \\
>20 \\
19-59 \\
18-60 \\
\text { Adult } \\
>16 \\
\text { Adult } \\
16-73\end{array}$ & $\begin{array}{l}4 \cdot 45 \\
5 \cdot 04 \\
5 \cdot 25 \\
5 \cdot 12 \\
6 \cdot 37 \\
6 \cdot 21 \\
6 \cdot 28 \\
6 \cdot 3 \\
5 \cdot 88 \\
5 \cdot 0 \\
5 \cdot 41 \\
5 \cdot 5\end{array}$ & $\begin{array}{l}2 \cdot 4 \\
9 \cdot 38 \\
4 \cdot 8 \\
\\
23 \\
6(>8 \cdot 3 \mathrm{mg} / 100 \mathrm{ml}) \\
17 \cdot 6 \\
5 \cdot 2 \\
8 \cdot 2 \\
7 \cdot 2\end{array}$ & $\begin{array}{c}\text { Enzymatic } \\
\text { " } \\
\text { Colorimetric } \\
\text { " } \\
\text { " } \\
\text { " } \\
\text { " } \\
\text { " }\end{array}$ \\
\hline $\begin{array}{l}\text { Women } \\
\text { Popert \& Hewitt (1962) } \\
\text { Acheson (1969) } \\
\text { Mikkelsen et al. (1965) } \\
\text { Hall et al. (1967) } \\
\text { Acheson \& O'Brien (1966) } \\
\text { Evans et al. (1969) } \\
\text { Garrick et al. (1972) } \\
\text { Isomäki \& Takkunen (1969) } \\
\text { Present study }\end{array}$ & $\begin{array}{l}\text { Wensleydale, UK } \\
\text { Watford, UK } \\
\text { Tecumseh, USA } \\
\text { Framingham, USA } \\
\text { New Haven, USA } \\
\text { Carterton, NZ } \\
\text { Sydney, Australia } \\
\text { Saloinen, Finland } \\
\text { UK }\end{array}$ & $\begin{array}{r}365 \\
163 \\
2118 \\
2489 \\
679 \\
197 \\
110 \\
1048 \\
252\end{array}$ & $\begin{array}{l}15-64 \\
\text { Adult } \\
15-74 \\
30-64 \\
>21 \\
20-69 \\
18-60 \\
18-60 \\
17-64\end{array}$ & $\begin{array}{l}3 \cdot 61 \\
4 \cdot 20 \\
4 \cdot 23 \\
4 \cdot 01 \\
4 \cdot 72 \\
4 \cdot 88 \\
4 \cdot 6 \\
4 \cdot 0 \\
3 \cdot 9\end{array}$ & $\begin{array}{l}0 \cdot 3 \\
2 \cdot 4 \\
0 \cdot 4\end{array}$ & $\begin{array}{c}\text { Enzymatic } \\
\text { ", } \\
\text { Colorimetric } \\
\text { ", } \\
\text { " } \\
\text { " }\end{array}$ \\
\hline
\end{tabular}

sen et al., 1965; Hall et al., 1967), a large French survey (Zalokar et al., 1972), and a smaller British study (Finn et al., 1966). They are considerably lower in both men and women than one other American survey (Acheson and O'Brien, 1966) and three Australasian surveys (Evans et al., 1969; Jeremy and Towson, 1971; Garrick et al., 1972).

Comparison of their findings with those of earlier Australian studies led Jeremy and Towson to suggest that there had been a true increase in SUA levels in the population over the previous 10 to 15 years and the same argument might apply when the present findings are compared with those of Popert and Hewitt. This would be in accord with the view that 'the associates of a high uric acid are the associates of plenty' (Acheson and Chan, 1969). However, sampling variation probably plays a large part in the differences between various surveys, particularly where the subjects are selected on the basis of employment or attendance at blood donor sessions.

For such reasons the subjects in this study may not have been completely representative of their regional population. However, when the regional groups were matched separately for age, physique, blood urea, and social class there were no significant differences in SUA levels between the groups (other than between the Winfrith and Birmingham women of social class IV/V). Indeed, the striking finding from this survey was the identical mean SUA level of the three male groups, and the closely similar levels in the two female groups.

The apparent rarity of gout in Scotland is unlikely therefore to be explained by regional differences in
SUA values. The prevalence of hyperuricaemia was a little lower, though not significantly so, in the combined English male groups (6.6\%) than in the Scottish group $(8.0 \%)$. It may be that Scotsmen are protected from the manifestations of gout in some other way; or, as we suspect, gout may have been uncommon in Scotland in the past but is less so today.

In certain populations and ethnic groups gout is said to be on the increase (Shichikawa, 1968; Talbott, 1976) and it might be expected that this would be mirrored in an increased prevalence of hyperuricaemia. Our findings cannot be taken to support this concept as far as the UK as a whole is concerned since, although the prevalence of hyperuricaemia in the men (Table 6) was higher than in one previous survey (Popert and Hewitt, 1962), it was very close to that in the other English group (Finn et al., 1966). Selection factors may explain, at least in part, national and international differences, though much higher prevalence rates for hyperuricaemia were found in the French and one Australian study (Zalokar et al., 1972; Jeremy and Towson, 1971). Similar considerations apply to the women although here there appeared to be closer agreement.

As expected, higher mean SUA levels were found in men than in women. The slight decrease in mean levels in women between the 3rd and 4th age decades is similar to that in other surveys and cannot be explained in terms of variations in obesity (Popert and Hewitt, 1962; Mikkelsen et al., 1965; Evans et al., 1969). The rise around the menopause has been 
attributed to hormonal influences (Mikkelsen et al., 1965), though a recent study carefully matching pre- and postmenopausal women of the same age (menopause defined as no menstruation during the previous 6 months) disclosed no difference between the two groups (Bengtsson and Tibblin, 1974). This definition of the menopause may not however exclude a falling-off of menstrual blood loss, and hence a rising haemoglobin, which is itself positively correlated with SUA (Acheson and O'Brien, 1966).

The known association of SUA with physique was also confirmed; it is of interest that there was a stronger correlation with body weight itself than with PI or LBM. Previous investigators have found a higher correlation with PI or relative body weight in men (Acheson and O'Brien, 1966; French et al., 1967), though our findings are in agreement to the extent that both weight and PI are more strongly correlated with SUA in women than in men. Although women have more adipose tissue per unit body weight than men, they also have less lean body mass and it seems that total weight is a better predictor of SUA than either of the other two physique calculations in both sexes.

The association of SUA with serum urea levels, even within the normal range, is unexplained but has been noted before (Kennedy et al., 1975), as has an association with serum creatinine (Decker et al., 1968). Both renal and metabolic mechanisms could account for this; aging may contribute as highly significant correlations of serum urea with age were found in both men $(r=0 \cdot 201)$ and women $(r=0 \cdot 355)$.

The very large contribution of sex to the total variation of SUA when compared with the other variables implies that other sex-associated factors which have not been taken into account, possibly hormonal (Nicholls and Scott, 1972), contribute significantly to the sex differences in SUA levels. Age and serum urea are seen to be less important than body weight as predictors of SUA in women, but retain their significance in men. However, the contribution of all these variables, apart from sex, is very small in practical terms.

The absence of a significant relationship between SUA and social class is in keeping with earlier findings (Acheson, 1969), but true poverty was probably lacking in the groups studied by Acheson and ourselves.

We are glad to acknowledge the technical assistance of Ian Moss and Peter Haisman; the collaboration of Dr. A. M. Laylee and Sister D. Newton at Winfrith; the kind collaboration of Dr. G. W. G. Bird, Director of the Regional Blood Transfusion Centre, Birmingham; and the statistical advice of Dr. K. Macrae in co-operation with Andrew
Jenkins and staff of Charing Cross Hospital Mediç School computer centre. The study was supported by the Arthritis and Rheumatism Council.

\section{References}

Acheson, R. M. (1969). Social class gradients in serum ure acid in males and females. British Medical Journal, 65-67.

Acheson, R. M., and Chan, Y.-K. (1969). New Haven survey of joint diseases. The prediction of serum uric acid in a general population. Journal of Chronic Diseases, 24 543-553.

Acheson, R. M., and O'Brien, W. M. (1966). Dependence ब्ग serum uric acid on haemoglobin and other factors in thes general population. Lancet, 2, 777-778.

Bengtsson, C., and Tibblin, E. (1974). Serum uric acid leves in women. Acta Medica Scandinavica, 196, 93-102.

Buchanan, M. J., Isdale, I. C., and Rose, B. S. (1965). Serung uric acid estimations. Chemical and enzymatic methods compared. Annals of the Rheumatic Diseases, 25, 285-288

Bywaters, E. G. L., and Holloway, V. P. (1964). Measure ment of serum uric acid in Great Britain in 1963. Annats of the Rheumatic Diseases, 23, 236-239.

Decker, J. L., Healey, L. A., and Skeith, M. D. (1968 Ethnic variations in serum uric acid: Filipino hypes uricaemia, the result of hereditary and environmentक factors. Population Studies of the Rheumatic Diseases, pp 336-342. Ed. by P. H. Bennett and P. H. N. Woo International Congress Series, No. 148. Excerpta Medica Amsterdam.

Dodge, H. J., and Mikkelsen, W. M. (1970). Observations the distribution of serum uric acid levels in participants the Tecumseh, Michigan, community health studie Journal of Chronic Diseases, 23, 161-172.

Evans, J. G., Prior, I. A. M., and Morrison, R. B. I. (1969 The Carterton study. 5. Serum uric acid levels of a sampte of New Zealand European adults. New Zealand Medic Journal, 70, 306-311.

Finn, R., Jones, P. O., Tweedie, M. C. K., Hall, S. M Dinsdale, O. F., and Bourdillon, R. E. (1966). Frequency distribution curve of uric acid in the general population. Lancet, 2, 185-187.

French, J. G., Dodge, H. J., Kjelsberg, M. O.. Mikkelsen, W. M., and Schull, W. J. (1967). A study of familiat aggregation of serum uric acid levels in the population of Tecumseh, Michigan, 1959-1960. American Journal if Epidemiology, 86, 214-224.

Garrick, R., Bauer, G. E., Ewan, C. E., and Neale, F. e (1972). Serum uric acid in normal and hypertensice Australian subjects. Australian and New Zealand Journal of Medicine, 4, 351-356.

Garrod, A. B. (1876). A Treatise on Gout and Rheumat Gout (Rheumatoid Arthritis), 3rd ed., p. 218. Longmans Green, London.

Hall, A. P., Barry, P. E., Dawber, T. R., and McNamara P. M. (1967). The epidemiology of gout and hype? uricaemia. American Journal of Medicine, 42, 27-37. $\omega$

Healey, L. A., and Hall, A. P. (1970). The epidemiology of hyperuricaemia. Bulletin on Rheumatic Diseases, 20, 600

Hume, R., and Weyers, E. (1971). Relationship between tota body water and surface area in normal and obese subject Journal of Clinical Pathology, 24, 234-238.

Isomäki, H. A., and Takkunen, H. (1969). Gout and hypert uricaemia in a Finnish rural population. Acta Rheum $\overline{0}$ tologica Scandinavica, 15, 112-120.

Jeremy, R., and Towson, J. (1971). Serum urate levels ar gout in Australian males. Medical Journal of Australia, $\Phi_{\text {. }}$ 1116-1118. 
Kennedy, A. C., Brennan, J., Anderson, J., Brooks, P., Buchanan, W. W., and Dick, W. C. (1975). Serum uric acid-its relationship to lean body mass, sex, plasma urea, intracellular potassium and packed cell volume in a normal population group. Paper read to meeting of Heberden Society at Norwich, 14th March, 1975.

Liddle, L., Seegmiller, J. E., and Laster, L. (1959). Enzymatic spectrophotometric method for determination of uric acid. Journal of Laboratory and Clinical Medicine, 54, 903913.

Mikkelsen, W. M., Dodge, H. J., and Valkenburg, H. (1965). The distribution of serum uric acid values in a population unselected as to gout or hyperuricaemia. American Journal of Medicine, 39, 242-251.

Nicholls, A., and Scott, J. T. (1972). Effect of weight-loss on plasma and urinary levels of uric acid. Lancet, 2, 12231224.

O'Sullivan, J. B., Francis, J. O'S., and Kantor, N. (1975). Comparison of a colorimetric (automated) with an enzymatic (manual) uric acid procedure. Clinical Chemistry, 11, 427-435.

Popert, A. J., and Hewitt, J. V. (1962). Gout and hyperuricaemia in rural and urban populations. Annals of the Rheumatic Diseases, 21, 154-162.

Registrar General (1970). Classification of Occupations. HMSO, London.

Shichikawa, K. (1968). The prevalence of gout in Japan. Population Studies of the Rheumatic Diseases, pp. 354-355. Ed. by P. H. Bennett and P. H. N. Wood. International Congress Series, No. 148. Excerpta Medica, Amsterdam.

Talbott, J. H. (1976). It happened on the way to the XIII International Congress on Rheumatology in Kyoto and after I had arrived. Arthritis and Rheumatism, 18, Suppl., 699-708.

Zalokar, J., Lellouch, J., Claude, J. R., and Kuntz, D. (1972). Serum uric acid in 23,923 men and gout in a subsample of 427 men in France. Journal of Chronic Diseases, 25, 305-312. 